\title{
Wespół w zespół, aby moc twórczą móc wzmóc, czyli o niełatwej sztuce budowania efektywnych zespołów
}

\section{Band together to step up our creative power - the difficult task of effective teams building}

\author{
Połączenie sił to początek, \\ pozostanie razem to postęp, \\ wspólna praca to sukces \\ Henry Ford
}

\section{Streszczenie:}

Generowanie pomysłów, tworzenie innowacyjnych rozwiązań, sprawne działanie oraz elastyczność to siła pracy zespołowej. Skuteczny i twórczy zespół jest mieszanką świeżości i doświadczenia, swobody i dyscypliny, zabawy i profesjonalizmu, improwizacji i zadaniowości. Tworzą go ludzie, którzy widzą sens swoich działań, ufają sobie i swoim kompetencjom, w pełni angażują się, świadomi swoich ról. Zgrany i nakierowany na realizację celów zespół to dobra inwestycja firmy i klucz do sukcesu.

Słowa kluczowe: budowanie zespołu, kreatywność, rola grupowa, komunikacja, praca zespołowa, efektywność, zachowania zespołowe, proces grupowy, twórczy potencjał

\section{Abstract:}

Generating ideas, create innovative solutions, proficient operation and flexibility is the power of teamwork. Efficient and creative team is a blend of 
Magdalena Maria Urlińska - Wespół w zespół...

freshness and experience the freedom and discipline, fun and professionalism, improvisation and task-oriented. It is composed of people who see the meaning of their actions, trust themselves and their competence, they fully engaged, being aware of their roles. Well-coordinated and targeted to achieve the objectives team is a good investment of the company and the key to success.

Keywords: team building, creativity, team role, communication, teamwork, efficiency team behavior, group process, the creative potential

\section{Wstęp}

Zarówno w życiu prywatnym jak i zawodowym komunikowanie się jest fundamentem wszelkich relacji. Sztuka skutecznego porozumiewania się oparta jest przede wszystkim na otwarciu się na drugiego człowieka. To w jaki sposób jednostki komunikują się ze sobą ma wpływ nie tylko na jakość ich życia, ale także tworzenie poprawnych relacji na gruncie osobistym, zawodowym czy społecznym. Akt komunikowania się jest narzędziem współpracy, wywierania wpływu, kształtowania społeczeństwa czy postrzegania otaczającej rzeczywistości, także tej organizacyjnej. Efektywne porozumiewanie się wprowadza „ład organizacyjny strukturyzując działania, budując hierarchię władzy, wyznaczając cele i zadania, akceptując je lub nie, oceniając skutek, sposób i czas ich realizacji"1. W związku z tym faktem, kluczowym zadaniem staje się budowanie porozumienia pomiędzy uczestnikami. Chodzi o to, aby tworzyć pomiędzy ludźmi mosty, a nie wznosić dzielące ich mury. Uważne słuchanie i interpretowanie treści komunikatów staje się punktem wyjścia dla współpracy. To, co w literaturze przedmiotu i praktyce określa się mianem pracy zespołowej, czyli efektywna wymiana informacji, świadomość własnej roli i wynikających z niej praw i obowiązków, poczucie zbiorowego współdzia-

\footnotetext{
${ }^{1}$ H. Czubasiewicz, Istota i rodzaje komunikacji w kształtowaniu zachowań odbiorców, [w:] Organizacja zachowań zespołowych, R. Rutka, P. Wróbel (red.), Warszawa 2012, s. 117.
} 
łania opartego na wzajemnym szacunku i współodpowiedzialności za proces decyzyjny, w efekcie staje się istotnym czynnikiem warunkującym rozwój każdej organizacji. Zespołowe współdziałanie daje efekt synergii (wzajemne uzupełnianie się jednostek), uwalnia potencjał intelektualny jednostek, umożliwia innowacyjne podejście do problemu, motywuje do dalszego działania, budując atmosferę zaufania w zespole. Jednak aby komunikowanie przebiegało sprawnie, a wyznaczone cele zostały osiągnięte, niezbędne jest wyeliminowanie wszelkiego rodzaju zakłóceń i trudności (barier i szumów komunikacyjnych), które ograniczają przepływ informacji.

Relacje interpersonalne i umiejętności komunikacyjne bezpośrednio przekładają się na jakość i skuteczność działania zespołu. 0 jego sile decyduje sprawna współpraca rozumiana jako „tworzenie wewnętrznych relacji, które ułatwiają odnalezienie pracownikom swojego miejsca w zespole zgodnie z obowiązkami, jakie do nich należą"2. Każda jednostka zaproszona do współpracy w ramach zespołu wnosi do niego indywidualny bagaż doświadczeń, potencjał, wiedzę i umiejętności, ale również własne potrzeby, interesy i emocje. To co warunkuje dynamikę i skuteczność działania to przyjęcie określonych zachowań. E. Markowska w kontekście dynamiki wymienia trzy rodzaje zachowań: zachowania zadaniowe (pomagają ustalić i realizować wspólny cel i zadania), zachowania zespołowe (spajają członków, wpływają na poczucie przynależności do zespołu) oraz zachowania indywidualne (niezaspokojone potrzeby indywidualne, które przeszkadzają w osiąganiu celów) ${ }^{3}$. Kontrolowanie stopnia nasilenia ww. zachowań przekłada się bezpośrednio na poziom współpracy lub rywalizacji. Utrzymanie optymalnych proporcji zachowań zadaniowych i zespołowych, przy jednoczesnej minimalizacji niepożądanych zachowań indywidualnych, zwiększa wydajność i efektywność zespołu.

\footnotetext{
2 E. Markowska, Budowanie zespołu, [w:] Organizacja zachowań zespołowych, R. Rutka, P. Wróbel (red.), Warszawa 2012, s. 95.

3 Por. ibid.
} 
Magdalena Maria Urlińska - Wespół w zespół...

\section{Razem znaczy skuteczniej}

Budowanie zespołów w miejscach pracy staję się coraz bardziej popularnym zjawiskiem. Pojęcie pracy zespołowej stosowane jest jako niezwykle nośne hasło, dobrze dobrany zespół staje się podstawą efektywnej współpracy i dzielenia się doświadczeniem przy dążeniu do realizacji celów. Różnice pomiędzy grupą a zespołem wynikają z ich liczebności, spójności, typu przywództwa oraz poziomu zaangażowania. W literaturze przedmiotu zespół traktowany jest jako zbiór ograniczonej ilości osób, systematycznie spotykających się, połączonych wspólnym celem, z jasno określonymi rolami i obowiązkami, przy czym cechuje je silna potrzeba współpracy oraz poczucie więzi pomiędzy członkami. To co staje się kluczowym elementem pracy zespołowej to realna współzależność zadań i kompetencji, zbiorowa decyzyjność oraz ciągła, niezakłócona komunikacja. B. Kożusznik określa mianem zespołu specyficzną, niewielką grupę społeczną, wewnętrznie spójną choć różnorodną pod względem składu osobowego, kierującą się określonymi normami, które określają standardy zachowań i regulują relacje pomiędzy jej członkami. Podsumowując powyższe definicje można przyjąć, iż zespół jest typem grupy osób, ściśle współpracujących ze sobą, świadomych odpowiedzialności za podejmowane decyzje i działania (tak indywidualne jak i zbiorowe), wspólnie poszukujących dróg rozwiązań, której miernikiem efektywności staje się ocena wypracowanych osiągnięć. Charakterystyczną cechą zrównoważonego zespołu jest fakt dzielenia się przywództwem, co w praktyce oznacza dzielenie się obowiązkami lidera w zależności od etapu pracy zespołu. Potencjał (indywidualne cechy, wiedza i umiejętności) każdego z członków zespołu może zostać wykorzystany w trakcie pracy, dlatego też niezwykle istotna staje się świadomość i głębokie przekonanie, iż zespół więcej zyska dzięki współpracy aniżeli pracy indywidualnej $j^{4}$.

\footnotetext{
4 Ibid., s. 75.
} 
Sukces współczesnych organizacji w dużej mierze zależy od pracy zespołowej. 0 skuteczności współpracy zespołu decyduje szereg czynników, przy czym kluczowy okazuje się system zarządzania. Stanowi on środowisko, przestrzeń codzienności, w której każdego dnia pracownicy mają za zadanie odnaleźć się w przypisanych rolach. Ten sam system może być zarówno źródłem synergii w zespole, jak i daleko posuniętego indywidualizmu ( $w$ negatywnym znaczeniu tego słowa). Skutecznie działający system zarządzania wyzwala w pracownikach chęć współdziałania, mobilizuje do dalszej aktywności, poszukiwania rozwiązań, wyznaczania sobie celów i pokonywania napotkanych barier. Zależność pomiędzy osobami zarządzającymi systemem, a funkcjonującymi w nim pracownikami, działa na zasadzie sprzężenia zwrotnego. Zarówno lider jak i członkowie zespołu wzajemnie oddziałują (w sposób świadomy, jak i nieświadomy) na swoje zachowania. Osobowościowe komponenty, motywacje, potrzeby czy system wartości determinują funkcjonowanie systemu. Współczesny menadżer kierujący zespołem pracowników, chcąc zrozumieć procesy zachodzące wewnątrz struktury, musi posiadać wiedzę na temat relacji interpersonalnych członków zespołu, ich indywidualnych predyspozycjach, zachowaniach, postawach i pełnionych rolach. Zespoły projektowe lub zadaniowe można znaleźć w prawie każdej instytucji, chociaż sami menadżerowie mają problem z określeniem czy mają do czynienia z zespołem czy raczej współpracującą ze sobą grupę ludzi. Nie każda bowiem grupa jest zespołem i nie każdy zespół jest grupą.

Zespół, jako zbiorowy autor osiągnięć, jest organizacją oparta na poczuciu jedności, spójności celu i misji. Praca zespołowa jest synonimem współpracy i zaangażowania, partnerstwa, wsparcia i zaufania, wzajemnego uzupełniania swoich umiejętności, eksperymentowania i nieszablonowego podejścia do zadania. Jest ciągłym poszukiwaniem złotego środka, kompromisów między indywidualnymi działaniami, a oczekiwaniami grupy. Ken Blanchard określa proces budowania zespołu jako „podróż - możliwy do przewidzenia proces przekształcania 
Magdalena Maria Urlińska - Wespół w zespół...

się zbioru indywidualności w dobrze funkcjonujący system"5. Posiadanie w organizacji zespołu jest źródłem twórczych rozwiązań, elementem zacieśniającym więzi, integrującym i mobilizującym do działania. Praca zespołowa dodaje energii, pozwala na uruchomienie potencjału drzemiącego w każdym człowieku, dając mu możliwość rozwinięcia skrzydeł, sprawdzenia się w nowych rolach, stawienia czoła nowym wyzwaniom. Efektywny zespół widzi sens tego co robi, wierzy, że warto coś robić razem, że potrafi i chce działać, że zależy coś od niego, elastycznie podchodzi do wyznaczonych zadań, uczy się na błędach, stale się rozwija. Jest przekuciem indywidualnego "Ja" w efektywne „My”, w oparciu o wartości takie jak jedność, spójność, tolerancja, partnerstwo, otwartość, zaufanie czy zaangażowanie. W ten sposób wspólnie budowany jest wizerunek firmy - organizacji opartej na przyjaźni. Członkowie zespołu nie tylko uczą się patrzeć w jednym kierunku i w jednej przestrzeni, łączy ich więź i poczucie, że tworzą coś nowego. Wraz z dojrzewaniem zespołu kształtuje się jego zbiorowa tożsamość. Wyraża się ona w skłonności do działania, dzielenia się informacjami, podejmowanie wspólnie decyzji, przedkładanie interesu grupy ponad własne ambicje.

\section{Uskrzydlony pracownik i jego bezcenny bagaż osobowości}

Każdy jednostka wnosi do zespołu coś niepowtarzalnego i twórczego - bezcenny bagaż swojej osobowości (kompetencje, doświadczenie, temperament, postawy, mentalność, potrzeby). Paradoks polega na tym, że mozaika osobowości może być równie kreatywna, jak i destrukcyjna. Różnorodność temperamentów, generowanie nieszablonowych pomysłów, odmienne perspektywy i indywidualne predyspozycje umiejętnie połączone mogą przynieść innowacyjne rozwiązania, nieskoordynowane mogą prowadzić do konfliktów i stereotypowego myślenia (myślenia grupowego). Praca w grupie jest współtworzeniem nowej rzeczywistości, uczy ludzi odpowiedzialności, profesjo-

\footnotetext{
${ }^{5}$ http://przywodztwo.home.pl/przywodztwo-w-biznesie/inspiracje/cytaty/
} 
nalizmu, stawiania sobie nowych wyzwań. Jest szansą na zdobycie nowych doświadczeń, uruchomienie nowych form aktywności, odchodzenie od schematycznego sposobu myślenia. Proces grupowy zaczyna się $\mathrm{w}$ momencie, gdy kilkoro ludzi spotyka się $\mathrm{w}$ tym samym miejscu, bo łączy ich wspólny cel (etap formowania grupy). Gra zespołowa opiera się na zasadzie synergii - uzupełnianiu się. Wraz z upływem czasu buduje się zadowolenie, atmosferę, zaufanie i wzajemny szacunek.

Razem można stworzyć wielkie rzeczy. Ważne, by dopasować rolę do predyspozycji osobistych członka grupy, aby odpowiedni człowiek znalazł się na właściwym miejscu. 0 wydajnym zespole można mówić w momencie, gdy zachowana zostaje równowaga wszystkich ról. Warto mieć w nim zarówno praktycznego organizatora, naturalnego lidera, jak i człowieka akcji, siewcę pomysłów, człowieka kontaktów, sędziego, człowieka grupy, perfekcjonistę czy specjalistę ${ }^{6}$. Interakcje są sposobem uczenia się nowych ról, przyswajania umiejętności grupowych, dlatego istotną cechą jest elastyczność, aby w sytuacjach trudnych przyjąć na siebie pewien zakres obowiązków. Właściwy dobór członków zespołu sprawia, że ludzie podchodzą z entuzjazmem do zadań. Znajomość swoich mocnych i słabych stron pozwala na skoordynowanie działań, skuteczne porozumienie i rozwiązanie problemów. Zespół to mikroorganizm i aby dobrze działał wszystkie elementy muszą współgrać ze sobą.

Praca zespołowa wymaga poszukiwania kompromisów między indywidualnymi działaniami a wymaganiami gry zespołowej. Nie wystarczy stworzyć warunków współpracy, aby pracownicy potrafili efektywnie działać, trzeba ich także odpowiednio zmotywować. Zarówno motywowanie do działania, jak i sama motywacja, jest istotna

\footnotetext{
${ }^{6}$ Por.: R. M. Belbin, Twoja rola w zespole, Gdańsk 2008; B. Rzepka, Efektywna komunikacja w zespole, Warszawa 2012; A. Kozak, Proces grupowy. Poradnik dla trenerów, nauczycieli i wykładowców, Gliwice 2010; K. Blanchard, Jednominutowy menadżer buduje wydajne zespoły, Warszawa 2010.
} 
Magdalena Maria Urlińska - Wespół w zespół...

tak dla pracownika jak i przełożonego ${ }^{7}$. Odpowiednie bodźce mogą zwiększyć wydajność pracy i sprawić, że pracownik z ochotą będzie realizował zadania oraz będzie identyfikował się z miejscem pracy. Nie wystarczy już podniesienie wynagrodzenia, trzeba znać potrzeby pracownika i w miarę możliwości wychodzić im naprzeciw. Wśród bodźców motywujących znajdują się: środki zachęty (płace, nagrody, pochwały, bonusy), środki przymusu (kary, ścisłe przestrzeganie procedur, system monitoringu pracy) oraz środki perswazji (informacje o celach, misji, wymaganiach przełożonego, uczestnictwo w ustalaniu celów czy w zarządzaniu) ${ }^{8}$. Proces motywowania w zależności od zależności od zmieniającej się sytuacji przechodzi kolejne etapy, od określenia celu pracy, zadań, kryteriów oceny realizacji zadań, przez poznanie celów i oczekiwań pracowników, dobranie właściwych bodźców motywujących, zastosowania elementów motywowania do pracy, obserwację i analizę postępów oraz zachowań pracowników, aż po sporządzenie oceny okresowej skuteczności systemu motywacyjnego. Zmotywowanie pracownika jest tożsame z „uskrzydleniem” go, wyzwolenie w nim chęci zmiany, zaangażowania, pozytywnego myślenia, chęci dzielenia się swoimi pomysłami oraz doświadczeniem z innymi. Chcąc stworzyć twórczy zespół trzeba pamiętać, że jego członkowie muszą mieć właściwą atmosferę, czuć wsparcie i akceptację przełożonego, mieć satysfakcję z tego, co robią i czuć się częścią zespołu oraz organizacji.

Budowanie twórczego zespołu wymaga pełnej mobilizacji i zaangażowania pracowników oraz menadżerów. Warto pamiętać zatem, iż są to działania długofalowe, do których potrzebny jest czas, energia i inwestowanie w rozwój pracowników. W perspektywie czasu praca zespołowa podnosi wydajność pracowników, usprawnia przepływ in-

\footnotetext{
${ }^{7}$ Aby skutecznie motywować pracownika, należy znać różnice między motywowaniem a motywacją. 0 ile motywacja to gotowość pracownika do realizacji celów i zadań, o tyle motywowanie jest procesem aktywizacji pracownika, obudzenie w nim twórczego potencjału i chęci do działania.

${ }^{8}$ Szerzej na temat motywacji w publikacji: J. Adair, Anatomia biznesu. Motywacja, Warszawa 2010.
} 
formacji, uelastycznia metodę podziału obowiązków, uczy jednostkę odpowiedzialności za powierzone zadania i zachęca do dzielenia się pomysłami. Efektywny podział pracy w ramach kooperacji dodatkowo redukuje schematyczny sposób myślenia w kategoriach „naszewasze". O zasadności i korzyściach posiadania w swojej organizacji zespołów świadczy fakt, iż w miejscach, gdzie funkcjonują one z powodzeniem, panuje przekonanie (zarówno wśród pracodawców, jak i pracowników), iż połączenie umiejętności pozwala przeanalizować więcej informacji, wypracować skuteczniejsze rozwiązania, a decyzje podejmowane zbiorowo są łatwiejsze do zaakceptowania przez jednostkę. Zespołowe współdziałanie daje członkom poczucie identyfikacji z firmą i projektami, przyczyniając się do wspólnego budowania wizerunku firmy.

Niekiedy praca w zespole może sprawiać wrażenie chaotycznej i wymykającej się spod kontroli, dlatego wymaga elastycznego i kreatywnego podejścia do zadań, modyfikowania przyjmowanych ról zespołowych w zależności od etapu prac. Niedopasowanie członków zespołu może rodzić konflikty i napięcia, dlatego tak ważnym elementem jest wzajemne zaufanie i wsparcie. Pozytywne myślenie i atmosfera w miejscu pracy, porozumienie i gotowość do zmian, zarówno pracowników jak i menadżerów, podnosi nie tylko wydajność organizacji, ale sprawia, że zespół pracuje z większą ochotą i silniej angażuje się w wykonywane zadania. Zespół jest mikroorganizmem, w którym sprawne działanie wszystkich osób gwarantuje sukces. Znajomość możliwości i słabości zespołu oraz metod tworzenia wydajnego zespołu pozwala na koordynowanie działań, skuteczną komunikację i rozwiązywanie problemów na bieżąco. Zgrany i nakierowany na realizację wyznaczonych celów zespół to dobra inwestycja firmy.

Budowanie, rozwijanie i zarządzanie kreatywnymi, efektywnymi zespołami to nie lada wyzwanie dla menadżerów. W wielu miejscach pracy funkcjonują raczej grupy pracownicze aniżeli zespoły, jednak widać realną potrzebę tworzenia form bardziej dojrzałych, opartych na pracy zespołowej. Podejmowanie trudu stworzenia dojrzałego 
Magdalena Maria Urlińska - Wespół w zespół...

i skutecznie działającego zespołu wiąże się ze zmianami jakie zachodzą w przedsiębiorstwach. Pomimo, iż w praktyce często próby tworzenia zespołu nie przynoszą oczekiwanych efektów, jest to forma intensywnie rozwijająca się. Wiele spośród organizacji stara się podkreślać wagę współpracy i potrzebę wykorzystania indywidualnego potencjału pracowników, aby uzyskać zamierzone cele. Uzasadnieniem tezy o potrzebie posiadania w swojej organizacji zespołu jest fakt, iż dzięki niemu członkowie aktywniej partycypują w działaniach. Funkcjonowanie w strukturze zespołu stwarza członkom możliwość uczenia się. 0 efektywności i sukcesie zespołu decydują czynniki zewnętrzne (miejsce zespołu w strukturze, dostęp do zasobów, doszkalanie pracowników, obowiązujące normy i przepisy) oraz wewnętrzne (dobrze dobrany skład zespołu, jasny podział obowiązków, rodzaj przywództwa czy zakres odpowiedzialności). Reasumując, społeczne, psychologiczne oraz moralne czynniki korzystnie wpływają na generowanie nowych, oddolnych inicjatyw, dając pracownikom poczucie satysfakcji.

W procesie tworzenia zespołu bierze się pod uwagę trzy aspekty: potrzebę zrealizowania określonego zadania, potrzebę satysfakcji z pracy jego członków oraz stworzenia atmosfery i warunków dla pracy zespołowej. Skład zespołu dobiera się pod kątem określonych zadań, z uwzględnieniem nie tylko kompetencji zawodowych czy indywidualnych predyspozycji przyszłych członków, ale także umiejętności współdziałania. Efektywny zespół to taki, który w swoich szeregach ma osoby, posiadające wiedzę i umiejętności techniczne, potrafią racjonalnie analizować problemy, ponadto są kreatywne, zdeterminowane do działania, zdolne do generowania innowacyjnych rozwiązań. Równocześnie potrafią budować relacje wewnątrzgrupowe, wychodzić naprzeciw oczekiwaniom i motywować innych do aktywnego angażowania się $\mathrm{w}$ pracę zespołową. 


\section{W świadomym zespole twórczy duch}

Kreatywność to zdolność ludzi do generowania pomysłów, tworzenia innowacyjnych rozwiązań. To aktywna postawa wobec problemów życia prywatnego i zawodowego, gotowość do zmian, elastyczność i ciekawość świata oraz ludzi. Budowanie i posiadanie kreatywnego zespołu jest niezbędnym warunkiem adaptacji do zmieniającej się rzeczywistości, potrafi on elastycznie dopasować się do potrzeb rynku i otoczenia, przez co odnosi lepsze wyniki. Innowacyjność zespołu to gwarant bycia atrakcyjnym i nowoczesnym na rynku. Sztuką jest połączenie eksperymentowania przy jednoczesnym utrzymaniu najwyższych standardów i procedur. Kreatywny zespół jest w stanie wykonać tę samą pracę szybciej, lepiej, wykorzystując każdą sytuację dla potrzeb zadania. Różnorodność myśli i punktów widzenia chroni przed schematycznym myśleniem, daje możliwość rozwinięcia dobrych pomysłów.

Tworzenie efektywnego i twórczego zespołu (kierującego się jedną spójną wizją i jasno wyznaczonymi celami) z osób o odmiennych postawach, przekonaniach, przyzwyczajeniach i charakterach, z indywidualnym bagażem doświadczeń jest zadaniem bardzo trudnym i wymagającym od kreatora (menadżera) niezwykłej elastyczności i znajomości specyfiki zadania. Musi on zdawać sobie sprawę z faktu, iż siła zespołu nie jest siłą indywidualną jednostek, to synergia, która warunkuje sukces, tworząc nową jakość pracy. Uzupełnianie się predyspozycji i umiejętności poszczególnych członków zespołu, odnalezienie się we własnej roli w grupie, pozwala na rozwój zespołu jako całości, jak również indywidualny każdego jej członka z osobna. Dopasowanie ról stanowi nie tylko siłę i atut zespołu, ale także jest źródłem samozadowolenia i satysfakcji jednostek ze współpracy. Kluczowym wyzwaniem każdego zespołu jest wypracowanie złotego środka pomiędzy indywidualną satysfakcją a osiąganymi sukcesami9.

\footnotetext{
${ }^{9}$ Więcej informacji na temat budowania zespołu w publikacji: B. Kowalczyk, P. Jordan, Budowanie zespołu, Warszawa 2001.
} 
Magdalena Maria Urlińska - Wespół w zespół...

Kreatywny i wydajny zespół jest zbiorem twórczych osób, kompetentnych, wierzących we własne możliwości, pozbawionych uprzedzeń, zdolnych do szerszego spojrzenia na problem i wypracowania alternatywnych rozwiązań. Istotną kwestią w funkcjonowaniu zespołu jest jego wewnętrzna spójność, „stan, gdy występują silne więzi społeczne między członkami zespołu, maja poczucie bycia zespołem i realizują cele zgodnie $\mathrm{z}$ akceptowanymi w grupie wzorami, standardami, normami"10. Czynnikami integrującymi zespół jest jego skład (wielkość, predyspozycje i dopasowanie członków), środowisko pracy (warunki fizyczne, charakter zadań, komunikacja, technologie), czynniki organizacyjne (styl zarządzania, typ przywództwa, polityka organizacji) oraz etap rozwoju i stopień dojrzałości zespołu. Przyczyn braku sukcesów w zespole można dopatrywać się w: ograniczonej autonomii zespołu (niedopasowanie struktur organizacyjnych do nowych wyzwań generuje sytuacje konfliktogenne we wzajemnych relacjach pomiędzy komórkami w strukturze instytucji), negatywnej rywalizacji pomiędzy zespołami (przepływ informacji celowo jest zbyt wolny, a bariery komunikacyjne są tak duże, że realizacja zadań jest odkładana lub opóźniana), myśleniu grupowym (wiąże się z wyizolowaniem zespołu, chęć przyłączenia się do niego podyktowana jest chęcią zysku, prestiżem, członkowie czują się zagrożeni, nie potrafią podjąć decyzji), podejmowaniu ryzykownych decyzji czy społecznym próżniactwie (zmniejszenie indywidualnej efektywności ze względu na fakt, iż rozliczany jest zespół jako całość ${ }^{11}$.

Mądrze i odpowiedzialnie kierowany zespół z czasem dojrzewa, podobnie jak normują się wzajemne relacje jego członków. Podstawowym zadaniem, jakiemu musi sprostać menadżer, jest pogodzenie (czasem rozbieżnych) oczekiwań, potrzeb i doświadczeń członków zespołu, dookreślenie nie tylko ról grupowych, ale także struktury, wzajemnych relacji i obowiązujących wszystkich członków zasad. Ścierające się ze odmienne poglądy i osobowości, na etapie tworzenia

\footnotetext{
${ }^{10}$ E. Markowska, Budowanie zespołu..., op. cit., s. 102.

11 Ibid.
} 
zespołu, generują niejednokrotnie sytuacje konfliktogenne. Niekontrolowane konflikty stają się w perspektywie czasu źródłem słabości organizacji. Aby im przeciwdziałać i rozładowywać narastające wewnątrzzespołowe napięcia kluczowe staje się wypracowanie systemu skutecznego rozwiązywania problemów. Jednym z rozwiązań jest informacja zwrotna (z ang. feedback), która „umożliwia wykorzystanie reakcji innych osób jako lustra, w którym możemy się bliżej przyjrzeć naszym działaniom (...) zwiększa ona świadomość poszczególnych członków zespołu co do tego, jak ich działania są odbierane przez innych"12. Wzajemny szacunek i zaufanie, zdrowe relacje i otwartość na dialog stają się punktem wyjścia dla konstruktywnych rozwiązań, a nie zarzewiem kolejnych konfliktów. Odzew musi być rzeczową, rzetelną oceną sytuacji, a nie odzwierciedleniem indywidualnych sympatii czy antypatii członków zespołu. Tam, gdzie brakuje otwartości, chowane urazy są jak otwierające się rany. Utrudniają normalne funkcjonowanie i działanie zespołu, co więcej negatywne emocje przybierają na sile, aby wybuchnąć w najmniej oczekiwanym memencie.

W rzeczywistości konflikt nie musi oznaczać destabilizacji i walki. Właściwie skanalizowany może stać się życiodajnym źródłem konstruktywnej krytyki. Wyjaśnienie nieporozumień, dogłębna analiza problemu, wprowadzenie zmian w efekcie może okazać się zbawienny dla realizacji celów. Wyeliminowanie problemów komunikacyjnych (takich jak chaos informacyjny, brak przejrzystych kryteriów podziału obowiązków, niespójność celów, niekonsekwencja, niedopasowanie osobowościowe w zespole czy pewne deficyty komunikacyjne) pozwala na sprawne funkcjonowanie zespołu i zapewnia zdrowe relacje pomiędzy jego członkami. Twórcze grupy posiadają paradoksalne cechy tj.: świeżość i doświadczenie, swobodę i dyscyplinę, zabawę i profesjonalizm, improwizację i planowanie. Swoboda w realizacji zadań musi być przyznawana z rozwagą, w granicach zdrowego rozsądku, zmiany powinny być wprowadzane w określonych obszarach,

12 B. Kowalczyk, P. Jordan, Budowanie zespołu, op. cit., s. 10. 
Magdalena Maria Urlińska - Wespół w zespół...

monitorowane, analizowane $\mathrm{w}$ kontekście całego systemu, tak by przewidywać i przeciwdziałać negatywnym konsekwencjom działań. Zespół działa jak jeden mechanizm, zatem efekty działań jednostki przekładają się na rezultaty pracy całego zespołu, dlatego tak ważnym elementem jest atmosfera, oparta na wzajemnej akceptacji, tolerancji i zaangażowaniu.

Sukces zespołu zależy w dużej mierze od lidera, który posiada umiejętność skupienia uwagi i skanalizowania entuzjazmu członków zespołu, w taki sposób, aby każdy z nich potrafił odnaleźć swoje miejsce, identyfikował się z grupą, współdziałał wraz z innymi, a nie konkurował. Poczucie odpowiedzialności, wspólnej misji zespołu, jasno określone cele i przejrzyste oczekiwania względem własnej roli w grupie, stają się niezwykle istotnymi elementami budowania nie tylko poprawnych relacji, ale $\mathrm{w}$ dalszej perspektywie efektywnego zespołu. Wydajne zespoły znacznie lepiej pracują aniżeli samodzielne jednostki. Zaangażowanie w działania większej liczby uczestników, pod czujnym okiem lidera, pozwala dostrzec szersze spektrum problemu i wypracować optymalne rozwiązania. Efektywnie pracujące zespoły potrafią dokonywać trafniejszych decyzji, chętniej podejmują ryzyko, stawiają sobie bardziej ambitne cele, dzielą się spostrzeżeniami. Wzajemne wsparcie członków zespołu wyzwala w jednostkach kreatywność, mobilizuje do dalszego działania, przyczyniając się jednocześnie do rozwijania ich indywidualnych umiejętności. Bycie częścią zespołu to niezwykła przygoda, dzięki której ludzie mają szansę rozwinąć się i odkryć swój potencjał. Otwarta komunikacja wraz z konstruktywną krytyką scala zespół, daje jego członkom poczucie dumy z bycia jego częścią.

\section{Zakończenie}

Budowanie twórczego zespołu wymaga pełnej mobilizacji i zaangażowania pracowników oraz menadżerów. Warto pamiętać zatem, iż są to działania długofalowe, do których potrzebny jest czas, energia i in- 
westowanie w rozwój pracowników. Generowania pomysłów, tworzenia innowacyjnych rozwiązań, sprawniejsze i wydajniejsze działania, elastyczność i nieszablonowość to niekwestionowana siła pracy zespołowej. Skuteczny i twórczy zespół jest mieszanką świeżości i doświadczenia, swobody i dyscypliny, zabawy i profesjonalizmu, improwizacji i zadaniowości. Tworzą go ludzie, którzy widzą sens swoich działań, ufają sobie i swoim kompetencjom, w pełni angażują się, wzajemnie motywuja, świadomi swoich ról i powierzonych im obowiązków, osoby otwarte na nowe pomysły, które w konstruktywnej krytyce i ścieraniu się opinii nie widzą zagrożenia, ale szansę na nowe spojrzenie i wyjście poza utarte schematy. Zgrany i nakierowany na realizację celów zespół to dobra inwestycja firmy i klucz do sukcesu. Twórczy potencjał ukryty jest w każdym z nas, wystarczy tylko dać mu szansę, aby się uaktywnił.

\section{Bibliografia:}

Adair J., Anatomia biznesu. Motywacja, Wyd. Emka, Warszawa 2010.

Belsky S., Realizacja genialnych pomysłów. Jak sprawić, by nie skończyło się na gadaniu, Wyd. Helion, Gliwice 2011.

Blanchard K., Jednominutowy menadżer buduje wydajne zespoły, Wyd. MT Biznes, Warszawa 2000.

Cutterbuck D., Coaching zespołowy, Wyd. Rebis, Poznań 2011.

Frederickson B.L., Pozytywność, Wyd. Zysk i S-ka, Poznań 2011.

Galata S., Zachowanie się ludzi w pracach zespołowych. Uwarunkowania, problemy, dylematy, Wyd. Difin, Warszawa 2008.

Horne T., Wootton S., Trenuj swój umysł czyli jak obudzić w sobie potencjał, Wyd. Edgard, Warszawa 2010.

Kowalczyk B., Jordan P., Budowanie zespołu, Wyd. Boris, Warszawa 2001.

Kozak A., Proces grupowy, Poradnik dla trenerów, nauczycieli i wykładowców, Wyd. Helion, Gliwice 2010.

Luecke R., Stwórz zespół z ikrq. Kompletny poradnik tworzenia wydajnych i skutecznych zespołów, Wyd. MT Biznes, Warszawa 2004.

Mackin D., Budowanie zespołu. Zestaw narzędzi, Wyd. Rebis, Poznań 2011. 
Magdalena Maria Urlińska - Wespół w zespół...

McKey M., Davis M., Fanning P., Sztuka skutecznego porozumiewania się. Praca - rodzina - zabawa, Wyd. GWP, Gdańsk 2007.

Nęcka E., Trening twórczości, Wyd. GWP, Sopot 2012.

Oech R. von, Kreatywność. Możesz być bardziej twórczy!, Wyd. Galaktyka, Łódź 2009.

Rutka R., Wróbel P. (red.), Organizacja zachowań zespołowych, Wyd. PWE, Warszawa 2012.

Rzepka B., Efektywna komunikacja w zespole, Wyd. Edgard, Warszawa 2012.

Stewart J. (red.), Mosty zamiast murów. Podręcznik komunikacji interpersonalnej, Wyd. PWN, Warszawa 2008.

Sweeney P., Greenberg H., Jak odnieść sukces i rozwinać swój potencjał, Wyd. MT Biznes, Warszawa 2007.

Szczepanik R., Budowanie zespołu: organizacja szkoleń team building i wypraw incentive. Poradnik dla menadżera personalnego, Wyd. Helion, Gliwice 2013. 